\title{
Via alruin en seks tot God: die eiesoortige mistiek in die poësie van T.T. Cloete
}

\begin{abstract}
In this article the researcher contends that T.T. Cloete, one of the most prominent contemporary Afrikaans religious poets, does not only periodically give expression to the mystical experience in his poetry (as Bosman [1989] would have it), but that the whole body of his poetic work is characterized by a distinctive mysticism. This mysticism, averse from the Catholic, ascelically inspired mystical tradition, is to be seen as a continuation and further development of the Protestant tradition with its greater emphasis on the earthly, general revelation of God, and is distinguished by its strong aesthetic basis and its lively topicality.
\end{abstract}

\section{Inleidend}

In wese is die poësie-oeuvre van T.T. Cloete 'n verwoording van en lofprysing op God se "deurlopende multimultimeervoud" (soos dit heet in "ubiquiteit", 1:133). ${ }^{1}$ Hiermee word verwys na die grootse samehang van die geweldige verskeidenheid korresponderende en/of disparate verskynsels wat in die kosmos waargeneem word. Hierdie dikwels paradoksale samehang openbaar die almag en liefdevolle sorg van die Skepper op só 'n wyse dat die ervaring daarvan die waarnemer in die Cloete-verse met verwondering en deemoed, maar ook met lewensvreugde vul. (Vergelyk onder andere "Van mossies en meer", $A: 5$; die reeks "Fyn vrugbare essensie", J:42-47; "holofrase", $I: 118$; "Paddastoeltuin", $D: 50$; die reeks "Landskappe", D:52-55; "Reis na Namakwaland", D:67; en "Paddaman", D:171.)

1 Afkorting van bundeltitels in dié artikel soos volg: $A=$ Angelliera, $J=$ Jukstaposisie, $A l=$ Allotroop, $I=$ ldiolek en $D=$ Driepas. 
Só 'n ervaring is klaarblyklik religieus van aard. Die "poëtika van korrespondensies" of die "poësie ... van jukstaposisie" wat Cloete volgens onderskeidelik Schutte (1984) en Hambidge (1990) op grond hiervan beoefen, is boonop nogal kenmerkend van die moderne religieuse letterkunde. Laasgenoemde word onder meer deur Glicksberg (1977:81) soos volg getipeer:

At the heart of the religious utterance, in poetry or drama or fiction of the twentieth century, is the awareness of the neverending endeavour to hold on to a faith that is elusive and paradoxical, a faith that cannot be grasped cognitively or verified empirically, a faith that transcends the limitations of language - above all, a faith that must be perpetually renewed if it is not to perish.

Die vraag is egter of só 'n ervaring as 'n mistieke ervaring getipeer kan word - of Cloete se poësie die etiket van mistiek kan/moet kry. Hoofsaaklik uitgaande van die studies deur Olivier (1985) en Bosman (1989) oor die Afrikaanse religieuse poësie (onderskeidelik die mistieke en die moderne Christelike tradisies) word in hierdie artikel geargumenteer ten gunste van sodanige tipering van Cloete se poësie. Die Cloete-mistiek is egter eiesoortig: aards, lewensdriftig, sterk sintuiglik en selfs sinlik. Daar word - soos dit in die gedig "verlore seun" $(D: 95)$ heet - via "alruin ${ }^{2}$ en seks ... aangeland by die Here". Miskien is dit dus meer juis, so word geredeneer, om eerder van 'n estetiese mistiek (of mistieke estesie) by Cloete te praat.

\section{Cloete en die Protestantse mistieke tradisie}

\subsection{Die skepping as goddelike openbaring}

Bosman (1989:294-302) stel dat Cloete, anders as byvoorbeeld Sheila Cussons (wat voortdurend en kenbaar probeer uitdrukking gee aan die hartstogtelike verlange na die unio mystica, die mistieke vereniging met God), slegs periodiek uiting gee aan die mistieke ervaring. Tipiese kenmerke van die mistiek wat sy wel in Cloete se digkuns onderskei, is onder andere die volgende:

* Die volslae religieuse oorgawe (met verwysing na gedigte soos "Diere", $J: 73$; "lag", Al:125; "kwiëtis", Al:36; "meelyfvoel", $A l: 35$; en "palingenese", I: 121).

* Die vooropstelling van lyding as folterende suiwering vir die mistieke vereniging (met verwysing na "antropatie", $A l: 50$ ). 
* Die belang van die voël/vleuels-kode in die uitdrukking van die transformasieproses tussen die pole aarde en hemel (met spesiale verwysing na "Voëls", J:72).

* Die siening van die digterskap as 'n religieuse geroepenheid (met verwysing na "lag", $A l: 125)$.

* Die ontdekking van die wesenlike en heilige in die alledaagse, en die gepaardgaande belang van $\mathrm{kyk} / \mathrm{sien}$ as 'n soort 'metafisiese handeling' (met verwysing na gedigte soos "Hy", Al:132; "Ergo sum", $J: 57$; en "Ons is", $J: 106)$.

'n Interessante opmerking wat Bosman (1989:298-299) in hierdie verband maak, raak die tradisie van die sogenaamde Protestantse Christelike mistiek in onderskeiding van die Rooms-Katolieke mistiek. Sy beweer dat die intellektuele inslag van Cloete se poësie "nie pas in die tradisie van die mistiek waar rede moet plek maak vir 'n blinde geloof en gerigtheid op die liefde van God nie". Dié digter "se voortdurende bewus-wees van die groot samehang en sy intense betrokkenheid by sy omwêreld", asook sy gevolglike "vreugde oor en liefde vir die ganse skepping", onderskei hom egter volgens haar eerder as Protestantse mistikus, in teenstelling met die Rooms-Katolieke mistieke tradisie wat "volkome onthegting van medemens en omgewing vereis".

Olivier (1985:63-66), wat sy proefskrif oor Mistiek in die Afrikaanse poësie juis onder die studieleiding van T.T. Cloete gedoen het, skryf ook in hierdie verband. In aansluiting by Happold (1977) tref hy ' $n$ onderskeid tussen twee breë strominge binne die tradisie van die mistiek, naamlik tussen die mistiek van kennis en begrip aan die een kant (meer intellektueel, spekulatief ingestel) en die mistiek van liefde en vereniging aan die ander kant (meer affektief en prakties ingestel). Binne albei strominge het daar egter ' $n$ bepaalde ontwikkeling voorgekom ten opsigte van die verhouding teenoor die omringende werklikheid. 'n Vroeëre fase, wat veral onder die invloed van die asketiese tradisie gestaan het en dus 'n onttrekking van die werklikheid voorgestaan het, het naamlik geleidelik oorgegaan in 'n besef "dat die intieme kennis van en liefde vir God neerslag moet kry in die lewe" (Olivier, 1985:65). Op grond van laasgenoemde benadering word die omwêreld nie meer ervaar as iets wat skeiding maak tussen die mistikus en die godheid nie, maar as " ' $n$ manifestasie van die vermoë en liefde van die godheid en 'n bevestiging van sy alomteenwoordigheid" (Olivier, 1985:65). Om hierdie rede, skryf Edsman (1970:10 en 11), is die mistieke ervaring

... ineffable, filled with a particular feeling of happiness and love for all things. The world is experienced as coherent and meaningful (...) and the experience thus implies new knowledge. In the brief experience of the 
depths of existence the sense of time and space is suspended or rather expanded.

Veral in die bundel Driepas - met die sprekende motto: "a humble love of earthly and divine things" - word presies dié soort ervaring redelik eksplisiet uitgedruk in gedigte soos "Vroue van Vermeer" (38), "By Haga-Haga" (42), "God die digter" (49), "naturalis" (57), "Reis na Namakwaland" (67), "die welkomsomhelsing" (72), "hutspot" (83), "onderhoud" (85), "kleinduimpiewerk" (146), "Karooklip" (154) en 'n hele paar uit die slotafdeling "Klawer". Om enkele grepe ter illustrasie aan te haal:

... En altyd is daar lig wat áfstraal in die liefs klein afgemete vertrek, oorvloedig, uit die oop grote universum en wat die klein aardse geslote stilte in die onmeetlike laat asemhaal.

("Vroue van Vermeer", $D: 38$ )

ons het die wondere van die skepping gedeel met mekaar ons het geringe opmerkings gesels gewonder in swye hoe die liefde óóit verveel of beangs kán wees en tuis gekom en mekaar omhels

asof ' $n$ groot fout nou herstel is

("die welkomsomhelsing", $D: 72$ )

Hierbinne voorlopig in ' $n$ dralende jaar is daar 'n dag, so 'n kosbare gewone dag, só eenvoudig en breekdun en klaar dat ons swygend in 'n skemertuin wag onder sterre om tot slaap te bedaar

sonder wyn, matig, donker en bedees, sonder dans of gesprek en sonder koïtus is dit ' $n$ sensitiewe, teer en fyn fees van nabye versadiging sonder enige lus anders as net om kosbaar tydsaam te wees.

("Draal", D: 183)

Ineens is daar vir ' $n$ kosbare hartseer oral plek in gras en voëls, daar is lelies en blare daarvoor en ons is daar, die weer en die lughemel, dit waai in 'n dun bries. Ons ontdek ons sê geen woorde meer 
vir mekaar nie. Daar kom 'n moment delikaat

en só heel dat ' $n$ enkele uur die waarde

van ' $n$ ganse bestaan het, met 'n oordaad

so gelade, so volmaak, dat die mees bedaarde

lispel dit rinkelend gaan stukkend praat.

("Seepbelsondagoggend", $D: 184$ )

\subsection{Kenmerkende kodes}

Dit is dan ook opvallend dat van die prominentste kodes van Cloete se poësie (soos onder meer deur Bosman, 1989:237 e.v. en Van Zyl, 1990:5 onderskei) juis kenmerkend van die genoemde latere, meer 'aardse' mistieke tradisie is.

\subsubsection{Komplekse samehang}

'n Mens dink hier in die eerste plek aan die gewaarwording van die komplekse samehang van die geweldige verskeidenheid skeppingsdinge - 'n deurlopende motief in die oeuvre van Cloete. Olivier (1985:79-80) beskryf die mistieke ervaring van hierdie grootse eenheid as ' $n$ "insig wat verby die intellektuele kennis strek" - of in die woorde van Spencer (1966:331) as "an awakening to truth and reality (to see) things as they really are". Dit is geen ontdekking van 'n vreemde wêreld nie, maar ' $n$ verligting en toeligting van wat voorheen nie behoorlik raakgesien is nie. Vandaar dat die belewing van 'n sekere "familiar strangeness" as een van die wesenstrekke van die mistiek onderskei word (vergelyk Olivier, 1985:76).

\subsubsection{Jukstaponering van hemel en aarde}

Samehangend hiermee moet die tweede belangrike (gemeenskaplike) kode gelees word, naamlik die teenstelling/jukstaponering van hemel en aarde. Olivier (1985:278-279 en 286) noem die teenstelling van twee onversoenbare wêrelde die sentrale organisasiebeginsel in die (ouer, meer asketies geïnspireerde - BJO) mistieke poësie. Dit is 'n teenstelling wat formeel neerslag vind in die kenmerkende benutting van die paradoks in dié soort poësie, en wat uitloop op die voorstelling van die gewone aardse werklikheid as skyn of onwerklikheid, asook op 'n intense verlange tot "die transformasie of transfigurasie van die bedrog- of skynwerklikheid ('hier') in die werklike werklikheid ('daar'), waardeur die 'daar' sy regmatige 'hier'-status sal kry".

Ook Cloete sien in dat die wese van die skepping waarin God sy grootheid openbaar, teenstellend en paradoksaal is - byvoorbeeld dat wanneer die leeu die springbok vang, "wat argeloos mooi/ is lê en spartel/ voor die gewelddadige mooi wat aanskoulik martel" ("Skouspel 1", J:12). God, self paradoksaal geweldig én genadig, openbaar Hom op derglike wyse in onder meer die "fisika" (Al: 109): 


\author{
hy laat hom vind \\ hy laat hom geld \\ in 'n solêre wind \\ en 'n geomagnetiese veld \\ met protone en elektrone bombardeer \\ die son die aarde sonder om ons seer \\ te maak 'n sagte kussing van magnetosfeer \\ beskerm ons sonder dat ons disintegreer \\ leef ons in onskuld \\ tussen geweldige kragte \\ ons kan hom duld \\ die ontsaglike sagte
}

Essensieel is egter die waarneming dat die teenstellings georden en verstrengel is. Trouens, dit is juis sy fyn waarnemingsvermoë wat die digter in staat stel om "ongerymdhede te laat saamrym" (Jansen van Rensburg, 1990:5), oin te kom tot 'n "saamdink van teenstrydighede" (Kannemeyer, 1988:451). Daarom kan Cloete se poessie "ten beste getipeer word as een van die jukstaposisie, van die verbandlegging tussen disparate dinge" (Hambidge, 1990:7) waardeur hy weer eens aansluit by die jonger mistieke strominge. In die sin wat dit uiting vind in Cloete se poësie, moet jukstaponering dus nie net as teenstelling van disparaathede verstaan word nie, maar ook as "naasmekaarplasing, teenoormekaar-plasing, ooreenskuiwing asook 'n dinamiese verhouding" (Jansen van Rensburg, 1990:5).

In Cloete se debuutbundel staan byvoorbeeld die gedig "Correspondances" $(A: 41)$, wat vanweë die titel en die spesifiek Franse spelwyse onmiddellik Baudelaire se gelyknamige gedig oproep. Baudelaire s'n is 'n gedig waarin die natuur (dikwels sinesteties) ervaar word as "'n tempel met 'n eie, mistieke taal" (Bosman, 1989:235). Cloete toon op verbeeldingryke wyse in sy gedig selfs 'n inniger verband oor ' $n$ wyer terrein van die skepping aan as Baudelaire, sodat ook die mens metafories één met die skepping word (Bosman, 1989:236):

Wimpers en wenkbrou het iets van 'n vlerk

van ' $n$ voël in vlug

van 'n swael in die swerk,

die oog iets van 'n vrug

van 'n bessie of kristal 'n juweel,

die hare is ' $n$ struweel, 
die neus dis iets

van 'n man gepunt iets hermafrodiets,

die mond

wat welf en swel

wil breek tot ' $n$ blom of ' $n$ wond,

die gloeiende blosende vel

het vrugtedons. Daar, wolke bo 'n afgrond,

maal onsekerhede rond.

Ook die reekse "Fyn vrugbare essensie" in Jukstaposisie en "Landskappe" in Driepas bevat goeie voorbeelde van gedigte waarin sodanige verbande (dit wil sê ook tussen mens en natuur) gelê word. Een voorbeeld uit eersgenoemde:

gedaantes word aan mekaar uitgedeel grond

aan my en ek aan die water

en dié aan vuur atome

swerf deur die hond

na die luis van die maankrater

na die fabriek vir drome

en atome is daar tussen die alg

en die komeet tussen die wolk en kameel

geen onderskeid nie stoom

word gegote vorm wat walg

van mekaar word speels ingedeel

in mekaar deur die eksperimenterende Taksonoom

("Swerf", J:45)

In 'n gedig soos "naturalis" uit Driepas (57) word die mens se vereenselwiging met die natuur selfs meer dwingend:

ek word al meer

julle tarentaal

njala

en ander familie

met julle konformeer

ek met my bas- en blaar- en mier-

water- aarde- dier-

en ander patie

en as ek na julle kyk elke keer

weet ek vir my én vir julle verstaan

dat ons almal in die groot roteer

binne die voorlê saam 
uiteindelik sal omgaan

in 'n onderons

onder- en bogronds

binne ' $n$ bestendige veranderlike Naam

\title{
2.2.3. 'n Panenteïstiese houding
}

Die strekking van 'n gedig soos laasgenoemde laat die vraag ontstaan of Cloete nie - soos Baudelaire (vergelyk Bosman, 1989:235) - 'n panteïstiese religie en poësie bedryf nie. 'n Nuttige onderskeiding is miskien dié wat Inge (1921:179) tussen panteisme ("everything is God") en panenteisme ("God is really in everything") maak. Dit is waarskynlik sodanige "panenteïstiese" houding wat gedigte soos "Lemmas I" (A:24), "holofrase" (I:118) en "Land van die eggo's" (D:119-120) binne die oeuvre van Cloete moontlik maak - gedigte waarin die blote opstapeling van substantiewe reeds die wonderbaarlike handewerk en daarom teenwoordigheid van God in aansyn (moet) roep. Byvoorbeeld:

\author{
goddelikheid is maal \\ argonout spiraal \\ krans \\ nimbus \\ wat dans \\ goddelikheid is diskus \\ wiel bus \\ werwel silinder veer \\ wringel siklus \\ ratel bal \\ rat met pal... \\ ("holofrase", I:118)
}

Ewenwel, in die newe-tradisie van die natuurmistiek dien die skoonheid van die natuur dikwels om die mens te 'roep' tot God. Die skoonheid van dit wat hom omring, word dan deur die geroepene gesien as 'n teken van die godheid; hy "identifiseer homself met hierdie natuur, en so word die vervreemding wat deur die mens se sonde ingetree het, opgehef' (Olivier, 1985:86-87). Wanneer dit gebeur, "man can (..) reclaim the beauty of nature, the divine in the natural" (Andreach, 1964:29), en word die mens opgevoer na 'n staat van eenwording met die godheid. 


\section{Die eiesoortigheid van die Cloete-mistiek}

\subsection{Aardsheid en lewensdrif}

Wat die mistiek in Cloete se poësie 'n eiesoortige skakering gee, is - soos gesê die intense aardsheid, sintuiglikheid en selfs sinlikheid daarvan. Dit is so dat sy poësie die "supersensuous meaning" adem wat kenmerkend toegevoeg word tot belewenisse in die mistieke staat (James, 1977:44). Tegelykertyd is die volgehoue strewe verby hierdie aardse werklikheid, die hartstogtelike verlange na 'n (vergeestelikte) unio mystica, egter opvallend gedemp of afwesig. Die twee idees wat deur Otto (1973:21) uitgesonder word as vooropgestel in die mistieke tradisie, naamlik "the ideas, first of the annihilation of self, and then, as its complement, of the transcendent as the sole and entire reality", word in sekere gedigte van Cloete selfs pertinent teengespreek. Gedigte soos "Eiewysheid" en "Hechten hier beneden" is sprekende voorbeelde. Vergelyk slegs die volgende :

ek moet vratig bly drink

en eet en sweet

en hondhyg ek moet vermoeiend bly dink

in teen die groot vergeet

("Eiewysheid", J.56)

(ek) stap met die bukkende korhane wat uit die

hemel en van die déúrvaloop verskiet

[wégvaldiep

wegbly en die wégtuimelende vlieg

vermy ...

("Hechten hier beneden", $J: 104$ )

"Paddaman" (I): 171-174), 'n haas ensiklopediese (hoewel verbeelde) verkenning van ondersese lewensvorme aan die hand van foto's in die National Geographic, sluit so:

Ek sal graag in hierdie baie vorme wil hoort.

Charon, as ek van die geliefde aarde sterf, gooi my dan asseblief hier oorboord

waar ek suksessief van vorm tot vorm kan bederf 
Daar spreek inderdaad ' $n$ volgehoue lewensdrif en lewensvreugde uit Cloete se poësie. Soos Bosman (1989:238) aangetoon het, word dié lewensdrif beklemtoon deur die tegniese ordeningstug, die snelle beelding, raak segging en stuwende ritme. 'n Mens sou hiertoe onder meer kon voeg die dinamiek van die balans tussen volgehoue eindryme, enjambemente en die gevolglike swewende sesuur, asook die gebruik van die apokoinou om 'n bepaalde spanning tussen voortstuwing en vertraging te bewerkstellig.

Hoewel verwant daaraan, is dit ook iets anders as die vreugde en ekstase wat in die kontak met die godheid tydens die (meer tradisionele) mistieke ervaring beleef word. Laasgenoemde, hoewel vergesel van 'n gevoel van tyd- en ruimteloosheid, het 'n vlugtige, verbygaande aard (vergelyk Olivier, 1985:78). Só 'n soort ervaring word byvoorbeeld uitgebeeld in gedigte soos "Draal" en "Seepbelsondagoggend" ( $D: 183-185)$, waarvan die slotstrofes vroeër aangehaal is. Die ekstase waardeur die grootste deel van Cloete se poësie egter gekenmerk word, hang saam met die poging om op volgehoue en omvattende wyse die onuitputlike wonderdade van "God die digter" (soos een van sy gedigte heet - D:49) na te speur en weer te gee. In 'n onderhoud met Elsa Krüger (1990:11) het Cloete byvoorbeeld gesê dat hy met Driepas 'n "katedraal" vir God wou bou met verskynsels daarin "van die waters onder die aarde tot in die hemele". Hierdie vreugde en ekstase is van die soort wat die ou man in "Hamster" ken:

Die hemel is vir hom so skrikwekkend hoog en ver. Hy bly hom gerus laag gedra op die aarde, sy as en erts, sout en loog. Ons sit hiér immers in die purgatoria. God hou ons hiér in die oog.

Hy sit diep versonke in sy tuin van avonture verwronge en van opgegaarde tyd. Die son brand liefdevol uit sy ver kruin vuur in sy vel, in sy naels, in sy baard en hou hom behaaglik lewensbruin.

Die krom grypende vingers, die dowwe paar oë en groot ore en lang neus wat degenereer, die vodderige vel, dit is alles kosbaar: al meer van wat gemaak is is al méér deur hulle beleef en bewaar en opgegaar.

$(D: 182)$ 


\section{2 'n Felle erotiek}

Uiting van sy lewensdrif is voorts die soms felle erotiek wat Cloete se poësie kenmerk.

Soos Bosman (1989:268) tereg uitwys, hang die erotiek in sy verse ten nouste saam met die religieuse besef van die digter, en vorm die "voortplantingsgedagte ... dus deel van die goddelike opdrag én beloning, die natuurbestel en goddelike orde in die skepping ... ". Die erotiek is inderdaad 'n belangrike ekspressie van die omvattende goddelike liefde wat Cloete in die skepping ervaar, en waardeur aansluiting gevind word by seker die belangrikste newe-tradisie in die mistiek, naamlik die liefdesmistiek. Dié newe-tradisie het as uitgangspunt die "oortuiging dat God liefde is, dat ons bestaan moontlik is alleen op grond van hierdie liefde, en dat God daarom ook die ware voorwerp van die liefdesoeke moet wees" (Olivier, 1985:84). 'n Allegoriese vertolking van die Hooglied en die (meestal kuise, maar soms heel sinnelike) huwelikmetaforiek staan in hierdie newe-tradisie sentraal in die uitbeelding van die vereniging van die siel en God. Dit noop Olivier (1985:86) om aan die slot van sy bespreking van die liefdesmistiek te bespiegel dat dit "interessant (sal) wees om te sien in welke mate die moderner skrywer hom eerder van sensuele lyflike beeldspraak gaan bedien as die tradisionele bruid-bruidegom-allegorie wat in die verlede so oorheersend was".

Reeds vroeg in die Cloete-oeuvre, naamlik in die "Tuin"-triptiek in Angelliera, blyk dit dat die motief van die erotiek ' $n$ belangrike in sy digkuns is. Talle gedigte daarna, waaronder ' $n$ hele aantal huweliks- en gesinsverse, bevestig dit. Dié motief bereik egter ' $n$ hoogtepunt in die afdeling "Flehmengrimas" in Driepas, byvoorbeeld met die drie musiekgedigte. Die eerste van die drie lui:

\section{konsert van die verliefdes}

eers is die twee koëkstensief

- die klavier, Korrelaat, en die viool, Grasie, haar maat molto mollig verlief

dan probeer die klavier die viool stuit, onttrek haar tydelik, wag stil, laat die viool snaarstyf wil, die klavier fladderdans vooruit

dan kom hulle na minute bymekaar geïntimeer paar paar paar paaarm kom gesinchroniseer 


\author{
maak gou klaar \\ met dat die tamboerstok slaan \\ op die trom se vliesdun membraan \\ hulle spil \\ van die skrik \\ vir die afluistering, lil, \\ snik
}

$(D: 22)$

Natuurlik vind ons geen ongekwalifiseerde viering van die erotiek in sy poësie nie. Dit word klaarblyklik slégs as bevestiging van die goddelike wil en betrokkenheid by die verwekkingsdaad beskou wanneer dit bínne die huweliksverband plaasvind:

\author{
Maar kyk kinders word uitgedeel \\ aan hulle deur die Here \\ as die man en vrou speel \\ sy opdrag aan Adam ter ere
}

("Psalm", J:34)

Anders, as "erogentriese spel/ in sigself gerig" ("Lyfspraak ongetroude swanger meisie", A:39), word dit in 'n aantal gedigte in die Cloete-oeuvre ontluister (onder meer in gedigte rondom die figuur van Marilyn Monroe, die "orgasmelose seksgenie" wat gely het aan "seksofrenie" soos dit in "ons eeu se aphrodite", $D: 26$, heet).

Dit word alles, soos Grové (1985) dit gestel het, "'n dankbare viering van die lewe self' - of in die woorde van Bosman (1989:272): "'n ekstase ... aangevuur deur die son wat hierdie digterskap letterlik deurstraal, en begelei deur die lag, wat so dikwels in hierdie poësie voorkom dat dit bykans op sigself kode word." (Terloops: die son is in die mistiek 'n belangrike goddelike simbool, soos dit onder meer voorkom in nog 'n mistieke newe-tradisie, naamlik die ligmistiek Vergelyk Olivier, 1985:88-90.)

\title{
3.3 Pyn en lyding as genade
}

Die teenpool van die ekstase is natuurlik pyn en lyding - ' $n$ volgende belangrike motief in Cloete se poësie sowel as in die mistiek. 
'n Belangrike fase van die via mystica is die sogenaamde fase van reiniging of onthegting (die via purgavita), tradisioneel onder meer gekenmerk deur 'n asketiese afsluiting van die sintuie en deur ervarings van pyn, wanhoop en verdriet (vergelyk Olivier, 1985:68-71). Soos voorheen aangetoon, dien pyn en lyding in Cloete se poësie eweseer tot folterende suiwering. Juis in die pyn word God se hand ontdek, soos uit 'n gedig soos "kunstenaar" (Al:38) blyk:

dis die doen van God wat formeer

om om te keer

sy instrumente maak almal seer

Hy kap my boom met sy byl

Hy gee aan my hout styl

met beitel en skreinende vyl

Deurdat pyn en lyding die digter in staat stel om die volle ervaring van die werklikheid deur te maak, stem dit hom tot dankbaarheid en dien dit as stimulant in die digterlike skeppingproses (vergelyk Bosman [1989:275-281], asook die uitspraak van Cloete teenoor Krüger [1990:11]: "As ek baie pyn het, is my gees hiperaktief").

Wat opval is dat die ervaring van pyn/lyding by Cloete, anders as in die tradisionele mistiek, eerder fisies as geestelik van aard is. By hom geen ervaring van "leegheid en 'n donkerte wat die siel laat wanhoop", die sogenaamde mors mystica nie (Olivier, 1985:72), maar eerder die sensasie van God se genadige teenwoordigheid juis in die pyn veroorsaak deur siektes:

sy mislukking

al wat been in my is

kan ek tel ps. $22: 18$

ek suig my vel

na binne aan my wurg

ek my skelet tel

ek ek proe my murg

ek lees dawid kromvingerlit

ek glo met my knersgebit

my hele weefsel is in staat

tot die helderste verstaan

van sy pynigende praat

in my neurasteniese bestaan 
ek is tot sy demonstratiewe beskikking

sy getroetelde mislukking

$$
(A l: 53)
$$

Die lyding word byna uitsluitlik in dié sin vergeestelik dat dit die lydende op God gerig hou:

... Dis deel van sy werk

om mens en voël tot vernedering so te breek

dat die heupbeensplinter en afvlerk

soos ' $n$ pinkie skeef en skerp na die hemel steek.

("Babbelwaggel", I:34)

Meer nog: Soos dit in "Job se lyftaal" $(I: 117)$ heet, is juis die banaal-aardse dikwels God-openbarend:

\author{
... wie soveel soos Job se God weet \\ van walg vomeer \\ tande eet \\ kos wat swak verteer \\ slegte smaak en dies meer
}

Hy IS

grondig reëlis

\title{
3.4 'n Estetiese mistiek
}

'n Mens kom tot die konklusie dat die mistieke ervaring by Cloete sterk esteties gekleurd is, dit wil sê indien esteties verstaan word in die sin wat byvoorbeeld Peter Abbs (1989:17) dit bedoel as ' $n$ "mode of intelligence" of ' $n$ "mode of human response and interpretation". Volgens hom is die estetiese die mees basiese modus van menslike respons, asook die mees primordiale modus van menslike intelligensie. Waar die menslike verstand in sy vermoë tot byvoorbeeld deduksie konsepsueel te werk gaan (analiserend, abstraherend, kategoriserend), gaan hy in sy vermoë tot estesie eerder persepsueel te werk (sensories én gevoelsmatig; onmiddellik integrerend).

Wat ons by Cloete vind is juis so ' $n$ primordiale Godsbelewing: 'n estetiese mistiek, of dalk mistieke estesie - hoe 'n mens dit ook al wil noem. In die gedig "verlore seun" (D:95) word die tradisionele godsdienstige leringe byvoorbeeld pertinent verwerp: "die masker van die streng oumansgesig/ met die wattebaard van die valsismes/ ... jeugdig wys en eiewys opgelig". In die belangrike slotstrofe 
word die terugpad na God dan (metonimies met alruin en seks) aangedui as die aardse en sinnelike:

...en tóé het ek pleks

van my behoorlik te bekeer

my oorgegee aan alruin en seks

en dáárlangs aangeland by die Here

Estesie moet egter nie begryp word as 'n bloot sintuiglike en/of emosionele ervaring nie. Die H.A.T. gee die betekenis van die Griekse persoonsnaam aisthetes byvoorbeeld aan as "waarnemer" én "begryper" - 'n kognitiewe element is dus gewis betrokke. Dit is eweneens die geval in die mistieke ervaring. Olivier (1985:64) wys byvoorbeeld daarop dat fasette van sowel die sogenaamde spekulatiewe as die affektiewe strominge in enige mistieke tradisie voorkom, "soms in 'n goed gebalanseerde ewewig, waar die denkers deur hulle bydrae 'n kenteoretiese basis probeer vind vir die ekstase waarvan die ervaarders probeer vertel ...".

Teen hierdie agtergrond word ' $n$ mens verlei om, ten opsigte van die besondere aard van die mistieke ervaring in Cloete se poësie, die meerduidige betekenismoontlikhede van die woord sinestesie te benut: dit wil sê enersyds as meervoudige sintuiglikheid of "(b)egeleidende gewaarwording" (H.A.T.), maar andersyds as estesie wat "sin"/kennis/insig tot gevolg het. lets dergeliks staan in die gedig "Wakker word" verwoord:

\begin{abstract}
.. Oorverdowend
polsend in 'n sinestetiese dik smoor ontstaan die dag. Ons moet die landskap óór die mórehorison langsteelkierie onverstoor instap en wat ons op die lyf gaan loop meegewend, onderdanig, in goeie geloof ondergaan. Dit is ' $n$ wonder: uit wat afstoot en ontroer, wat knel en beroer, walg en bekoor ontstaan daar tog leefbaar 'n sintoon.
\end{abstract}

Dié bepaalde kennismoment wat in spel kom, vind in die Cloete-poësie markant neerslag in epigrammatiese, eksegetiese formulerings, dikwels in gedigslotte (soos onder meer Malan [1990:100] en Spangenberg [1990:17] uitgewys het) Om by die voorbeelde hierbo nog enkeles uit Driepas aan te haal: 
Die poësie laat hom geld

met delikate geweld

$$
\text { ("Zeus vandag", D: 14) }
$$

die aarde is deur ' $n$ digter gemaak

("God die digter", $D: 49$ )

God ryk en oorvloedig

- die blomme het dit in oorvloed gewys -

se geliefste liefde is armoedig

("Reis na Namakwaland", $D: 67-71$ )

\subsection{Aktuele betrokkenheid}

By laasgenoemde aspek, naamlik die kennismoment in die estetiese ervaring, sluit die betrokkenheid by die aktualiteit en die meestal implisiete, maar dikwels ook eksplisiete sosiale kommentaar in sy poësie aan (byvoorbeeld met betrekking tot die uitspattighede van hedendaagse jongmense, tot die kommersiële uitbuiting van vroulike seksualiteit, tot die onvermoë van 'n literêre kritikus, ensovoorts).

Ook die aanwending van buitengewone woorde waarop resensente soos Malan (1990:100), Spangenberg (1990:17) en Van Zyl (1990:5) gewys het, moet myns insiens in hierdie lig verstaan word. Met buitengewone woorde word bedoel: wetenskapswoorde, woorde en aanhalings uit ander tale en tekste, neologismes, minder gebruikte woorde - kortom: 'intellektuele' woordeskat. Soos die opgestapelde selfstandige naamwoorde in byvoorbeeld "Lemmas I" (A:24), "Land van die eggo's" ( $D: 119-120)$ en die reeds aangehaalde "holofrase" (I:118), roep hierdie woorde verskynsels, sake en kwaliteite wat die goddelike almag verklap, as ' $t$ ware in aansyn. In hierdie geval is dit dinge wat dikwels buite die ervaringsen kennisveld van die gemiddelde mens val, dinge wat behoort tot byvoorbeeld die historiese of geologiese, die mikrokosmies kleine of makrokosmies grote. Sodoende funksioneer hierdie soort woorde (soos "prokrustes", "afasiese", "rubrikator", "hydraïeke", "geogeraas", "alcynoriumkoraal", "katabolisme", ensovoorts) as instrumente - of, ja: sintuie waarmee selfs 'minder bekende' kante en uithoeke van die skepping verken word. Laasgenoemde is iets wat die digter hom pertinent ten doel stel, byvoorbeeld in "prospekteer" (I):151): "ek gaan na die sentrale en omvattende op soek ...".

Ook in hierdie opsigte wyk Cloete dus af van die tradisionele mistiek. Soos Olivier (1985:294-295 en 301-303) aantoon, het die gerigtheid op 'n transendente werklikheid tot gevolg dat die strak, wetenskaplike wêreld algeheel en opvallend afwesig is in die tradisionele mistiek; voorts dat spesifieke politieke en sosiale betrokkenheid ontbreek ten gunste van 'n radikale en allesomvattende sosiale kommentaar. 


\subsection{Ikoniseringsdrif}

Dit is te wagte dat die bepaald estetiese aard van die Cloete-mistiek formeel neerslag in sy poësie sal vind. Hieraan sou 'n mens uiteraard 'n uitgebreide studie kon wy. Genoeg om te sê dat byvoorbeeld die ervaring van die grootse en gejukstaponeerde samehang van die skeppingsdinge verstegnies verreken word in onder meer die volgende:

* die verstommend volgehoue, hegte klank- en rymbindinge,

* die prominente gebruik van die aaneenskakelende enumerasie-tegniek,

* die funksionele aanwending van die apokoinou en van die tipografiese wit in plaas van leestekens om sintaktiese en semantiese ineenvloeiing te bewerkstellig en

* die snelle beelding waardeur disparaathede verrassend in verbinding gebring word.

Hierby sluit die digterlike procédé van intertekstualiteit aan waardeur Cloete in die woorde van Pretorius (1987:36) "demonstreer ... dat die Afrikaanse letterkunde deel is van die literêre tradisie en van die literatuur van alle eeue".

Dit vind egter ook neerslag in die totale strukturering van enkelbundels ${ }^{3}$, selfs in die strukturering van bundelgroepe ${ }^{4}$. Trouens, die poësie van Cloete verraai wat Bronzwaer (1990:99) 'n "iconiseringsdrift" sou genoem het. Ikonisiteit, deur Van Zoest (1978:104-105) as die mees fundamentele betekening beskou en deur onder andere Bronzwaer (1990:97) as die uitstaande kenmerk van poëtiese taalgebruik bestempel, is wesenlik 'n benutting van "gemarkeerde ongrammaticaliteiten" (Bronzwaer, 1990:99) om iets van die fundamentele relasie tussen teken en betekende te herstel - om dus iets van die estetiese as basiese modus van

3 Vergelyk byvoorbceld dic wysc waarop dic gedigte in dic bundel met dic titel Allotroop nie in afdelings verdecl is nic; of dic 'katedraal'-tcktonick van Driepas waarna hicrbo verwys is.

$4 \quad$ Vergelyk dic wysc waarop Bosman (1989:312-318) trag om aan te toon dat Cloctc dic cerste vier bundels "gckomponecr" het op dic grondvorm van dic sonate, met Angelliera as "cksposisic" en "aankondiging van die hooftema in dic hooftoonaard", Jukstaposisie en Allotroop as "dic ontwikkeling of verwerking in verwante toonaarde", en ldiolek as die derde decl, "dic herhaling of samevatting". 
menslike ervaring in die taalhandeling self te laat spieël (vergelyk Odendaal, 1991.)

In die lig van al bogenoemde verras dit dan nie om te verneem dat mistici van oudsher af ' $n$ voorliefde vir die poësie as medium tot ekspressie van die mistieke ervaring koester nie (Olivier, 1985:8). Mistiek en estetiek gaan saam op grond van die 'gewaagde', 'afwykende' aard van poëtiese taalgebruik. Olivier (1985: 105-106) noem dat daar ' $n$ strewe by mistieke digters is om woorde terug te herlei na hul "oorspronklike betekenis", om "die eerste verhouding tussen fenomeen en sy teken te herstel". Dis 'n strewe na wat Bronzwaer (1969:180) "de sacramentalisering van de binnenwereldlijke werkelijkheid" genoem het, en vind neerslag in 'n analogiese woordgebruik: "woorde of voorstellings uit die sintuiglike wêreld word gebruik om te praat oor dit wat die sintuiglike wêreld transendeer" (Olivier, 1985:103).

Daarom is die taal van die mistiek relatief ryk aan beeld, vergelyking en metafoor - "a device which keeps words close to the intense moment of experience: metaphor is not just the best words in the best order, but rather experience in the most dynamic syntax" (Peterkiewicz, 1970:43). Hierdie woordwêreld is tradisioneel ontleen aan die twee sfere van die natuur en die liefdesverhouding tussen man en vrou (binne die Protestantse tradisie ook van die Bybel). Mettertyd het dit, onder meer op grond van die benutting van die herhalingstegniek om die bepaalde religieuse 'geladenheid' van sekere terme te beklemtoon, redelik geyk geraak, in 'n eie retoriek ontwikkel: 'n taal "gemanipuleer ... om sy oortuigendste en meevoerendste sê te sê" (Olivier, 1985:111-120).

Sodanige taalgebruik is ook al weer iets anders as die ikoniseringsdrang, en miskien eerder iets verwant aan wat vroeër gesê is oor die in aansyn roep van fenomene wat God se vingermerke verklap deur die blote opnoem van substantiewe. Tog is dit interessant om daarop te let dat juis die herhaalde benutting van sommige strategieë wat hierbo as ikoniserend aangedui is, mettertyd gelei het tot kritiek dat Cloete se poësie ontaard het in "styl-oordaad en styl-opsetlikheid (maniërisme)" (Spangenberg, 1990:17). Daar is selfs gesê dat dit verval het in "eenselwigheid" (Scholtz, 1990:11); dat Cloete "die slagoffer van sy eie retoriek geword het" omdat "te veel gedigte deur hulle veelwoordigheid en meganiese toepassing van tegnieke 'n kunsmatige indruk (maak)" (Kannemeyer, 1988:455).

In elk geval: Soos wat die mistikus, ten spyte van 'n besef van die onsêbaarheid of onoordraagbaarheid van die mistieke ervaring, hom profeties geroepe voel om tog sy ervaring oor te dra aan ander (Olivier 1985:96), so voel die digter in Cloete se poësie dat sy digterstaak hom opgelê is. "Dit is as't ware biologies in hom ingeskape", skryf Bosman (1989:289). In "wat ek moet onthou om te bid" heet dit byvoorbeeld: 
... bly skei genoeg adrenalien

af vir poësie hou tog aan stoof

aan die stil krag van die geloof

hou die oog vol chromatiese illusie

behou die himniese tong se elokusie

(Al:60)

En tog bly iets altyd ongrypbaar vir woorde, ontglip daar iets aan die pogings om God in die skeppingsdinge te vind (soos in 'n hele aantal gedigte, veral uit Driepas, bely). Ons bly "beduimelaars":

ons deel die skepping in ... in die leemtes ontsnap

iets Groots alle taal en wetenskap

$(D: 145)$

Of soos dit aan die slot van die gedig "prospekteer" lui:

... ek bly reis bly soek. Hy die Here

is gekamoefleer, gediversifeer, oneindig eindeloos meer

mega- as enkelvoudig geformuleer.

$(D: 151)$

In weerwil van die bewussyn van digterlike geroepenheid en in weerwil van die andersins vrymoedige, openhartige en taamlik informele aanslag wat Cloete se belewing van en kontak met God kenmerk (vergelyk Bosman, 1989:278), is daar 'n besef van eie, menslike nietigheid voor ' $n$ ontsagwekkende Skepper. Dis 'n besef wat die digter in ' $n$ milde, meestal weldadige humor as verdere motief dwarsdeur sy oeuvre verdiskonteer.' Die talle lag-gedigte getuig reeds hiervan, maar ook byvoorbeeld 'n gedig soos "Ballade van die digter" (I:66-67). In laasgenoemde verkondig ' $n$ engel dat God besluit het om die oordeelsdag uit te stel ter wille van die opskrywende digter - dié "guit" en "ydeltuit" wat "in die lang sloer/van die eeue en aarde 'n roekelose ydel gesprek/ met ewighede (...) voer".

3 Dit versterk dic argumentasic in dié artikel wanneer Olivier (1985:76) aantoon dat iemand soos Scharfstein (1973) "humour" as cen van dic elf wescnstrckke van die mistick uitlig. 


\section{4. 'n Calvinisties-Christelike mistiek?}

In die lig van Cloete se verbintenis met die Calvinisme ${ }^{6}$, bly dit natuurlik 'n vraag hoe Calvinisties en Christelik sodanige mistiek is. Olivier (1985:5) en Heyns (1982:101) wys byvoorbeeld daarop dat die kern van die tradisionele mistiek, naamlik die wêreldversaking en toespitsing op die kontemplatiewe lewe in die strewe na eenwording met God, wesenlik vreemd staan aan die (Calvinisties-) Christelike belydenis dat alleen die soenverdienste van Christus dit vir die deur sonde gekorrupteerde mens moontlik mak om persoonlike kennis van en 'n persoonlike verhouding met God te hê.

In die lig hiervan val dit byvoorbeeld op dat daar in Cloete se poësie selde, indien ooit, 'n direkte verwysing na Jesus Christus voorkom, en dat die ryke intertekstuele jukstaponering van die Bybel met Cloete se poësie hoofsaaklik vir die Ou Testament geld. Aan die ander kant vind ons in hierdie poësie geen wêreldversakende, suiwer kontemplatiewe ingesteldheid en geen 'losheid' van die Woord nie; inteendeel. Bowendien is die gedagte van ' $n$ 'mistieke' eenwording met Christus (die genadige deelhê aan sy sterwe en opstanding) nie so vreemd aan die Christelike geloofsleer nie; dit is ' $n$ wesenlike deel van die soteriologie (Jansen van Rensburg, 1990:126-127). Myns insiens moet die mistieke ervaring in Cloete se poësie in laasgenoemde sin verstaan word. Daar word met nuwe oë gekyk na die skepping en na die self (hoe verwronge en ontaard ook al). Daar word ontdek hoe God hom in sy genade openbaar in alles wat ons omring, ook in onsself. Dit is ' $n$ bevrydende en reddende ervaring, ' $n$ 'nuutmaking': dit vul die mens met skaamte (vergelyk gedigte soos "kwiëtis, $A l: 36$, en "uitpraat", $D: 45$ ), maar ook met verwondering, nederige dankbaarheid, liefdevolheid en lewensywer. "(L)ife is in the eye of the beholder", soos een van die afdelings in ldiolek heet.

Dié 'nuutmaking' in die ontdekking van die grootse samehang van dit alles is nie die resultaat van die menslike inspanning en strewe nie, en nie iets wat eers in die hiernamaals in volvoering gaan nie, maar 'n genadegawe wat die intens meelewende mens, hier op aarde reeds, te beurt val. lets hiervan word in die gedig "hiskia" verwoord (onder 'n motto uit Jesaja 38:2: "neem tog in ag dat ek .../ met volle oorgawe geleef het"):

6 Aanvanklik was hy teologiestudent en heelwat later literator aan dic PU vir CHO. Sy verbintenis spruit natuurlik ook gewoon uit sy geloof. 


\begin{abstract}
kyk aandagtig na my bekyk my
julle wat tydsaam verveeld sit en tuur

deur julle vensters na die straat

wat in julle motors versonke verby

my ry ek het met my gesig na die muur

gekrul gelê die Here omgepraat

ek het hom vir jeremia hoor sê

'n groot man wat so ontroosbaar

huil om die lewe in gebede lastig lol

moet gegun word om my langer lief te hê

gooi die graf vir nog vyftien jaar

toe laat die son tien trappe terugrol

sit 'n vyekoek op sy oog

laat hom dit eet en laat hom proe

laat hom snuffel aan die geur

daarvan laat sy vinger dit voel droog

sy trane af reinig sy ore laat hom toe

om my nog langer deur hom te laat gebeur
\end{abstract}

(Al: 120)

Hoewel nie by name nie, is ' $n$ gedig soos hierdie ' $n$ ekspressie van die kern van die Christelike (en Reformatoriese) opvattings aangaande die goddelike verlossingswerk? ${ }^{7}$ Wat egter weer eens opval, is die sterk aardse, sintuiglike ervaring van dié hemelse genade.

\title{
5. Ten besluite
}

Terugskouend wil ek dus van Bosman (1989:227) verskil waar sy Cloete as religieuse digter tipeer wat net periodiek uitdrukking gee aan die mistieke ervaring. Na my mening staan sy ganse poësie-oeuvre in die teken van 'n eiesoortige mistiek. Hierdie mistiek is wars van die asketies geïspireerde mistieke tradisie, maar is terselfdertyd ' $n$ voortsetting en verdere ontwikkeling van die Protestantse tradisie met groter klemplasing op die teenswoordige, algemene openbaring van God. 'n Sterk estetiese grondslag en lewendige aktualiteit (wat dus ook 'n sekere intellektualiteit en 'n verrekening van byvoorbeeld die modeme wetenskapswêreld moontlik maak) is die vernaamste onderskeidende kenmerke van hierdie mistiek.

7 Bosman (1989:263) beskryf dić gedig as "inderdaad 'n opstandingsgedig, waarin dic dood volkome vanuit 'n Christelike perspekticf gehanteer word". 
Op hierdie wyse lewer Cloete ' $n$ belangrike bydrae tot die Afrikaanse religieuse én mistieke poësie, en sorg hy vir die soort vernuwing waarsonder die geloofslewe van die twintigste-eeuse mens waarskynlik sou kwyn (soos verwoord in die waarskuwing van Glicksberg wat aan die begin van dié artikel aangehaal is).

\section{Bibliografie}

Abbs, P. 1989. Tactful Approach to Life. The Times Higher Education Supplement: 17, Jan 15

Andreach, R. 1964. Studies in Structure. London: Burns \& Oates.

Bosman, M.E. 1989. Op Hom die groot hosamas : enkele aspekte van die moderme Christelike poësie in Afrikaans. Grahamstad : Universiteit Rhodes. (Ph.D.-proefskrif.)

Bronzwaer, W.J.M. 1969. Vormen van imitatie. Amsterdam : Athenaum Polak \& Van Gennep.

Bronzwaer, W.J.M. 1990. Poëzie en ieoniciteit. Forum der Letteren, 31(2) : 93-103, Junie

Cloete, T.T. 1980. Angelliera. Kaapstad: Tafelberg-Uitgewers.

Cloete, T.T. 1982. Jukstaposisie. Kaapstad: Tafelberg-Uitgewers.

Cloete, T. T. 1985. Allotroop. Kaapstad: Tafelberg-Uitgewers.

Cloete, T.T 1986. Idiolek. Kaapstad : Tafelberg-Uitgewers.

Cloete, T.T 1989. Driepas. Kaapstad : Tafelberg-Uitgewers.

Edsman, C. 1970. Mysticism, Historical and Contemporary. In : Hartman, S.S \& Edsman, C. (eds.) : Mysticism. Based on Papers read at the Symposium on Mysticism held at Abo on the 7th-9th September, 1968. Stockholm: Almquist \& Wiksell. p. 1-13.

Glicksberg, C.I. 1977. Literature and Religion. Westport, Conn. Greenwood Press.

Grové, A.P. 1985. Allotroop een van die belangrikstes. Beeld: 14, Julie 1.

Hambidge, J. 1990. Lywige Driepas sleur mee. Die Transvaler: 7, Februarie 13

Happold, F.C. 1977. Mysticism, a Study and an Anthology. Hammondsworth: Penguin Books.

H.A.T

$k y k$

Odendal et al. 1981

Heyns, J.A. 1982. Teologiese etiek. Pretoria : N.G.-Kerkboekhandel.

Inge, W.R. 1921. Studies of English Mystics. London: John Murray.

James, W. 1977. The Varieties of Religious Experience. Glascow : William Collins.

Jansen van Rensburg. J.H. 1990. Die jukstaponering van hemel en aarde in die poësie van

T.T. Cloete. Potchefstroom : PU vir CHO. (M.A.-verhandeling.)

Kannemeyer, J.C. 1988. Die Afrikaanse Literatuur 1652-1987. Pretoria en Kaapstad Academica.

Krüger, E. 1990. Die man het 'n katedraal gebou in 'n jaar. Beeld: 11, Februarie 10.

Malan, L. 1990. Virtuoos, maar te veel. De Kat: 100, Maart

Odendaal, B.J. 1991. Sien (en hoor!) is glo : 'n voorlopige verkenning van ikonisiteit as retoriese strategie aan die hand van twee kort gedigte. Literator, 12(3):13-23, Nov.

Odendal, F.F., Schoonees, P.C., Swanepoel, C.J., Du Toit S.J., Booysen, C.M. 1981 Verklarende Handwoordeboek van die Afrikaanse Taal Johannesburg : PerskorUitgewery. Tweede uitgawe, tweede druk

Olivier, S.P. 1985. Mistiek in die Afrikaanse poesie. Potchefstroom : PU vir CHO (D.Litt.proefskrif.)

Otto, R. 1973. The Idea of the Holy. An Inquiry imto the Nonrational Factor in the Idea of the Divine and its Relation to the Rational. London : Oxford University Press 
Peterkiewicz, J. 1970. The Other Side of Silence. The Poet at the Limits of Language. London : Oxford University Press.

Pretorius, R. 1987. Kanttekeninge by T.T. Cloete se vierde digbundel. Tydskrif vir Letterkunde, XXV :2 : 27-37, Mei.

Scholtz, M. 1990. Verskeidenheid, maar ook eenselwigheid. Die Burger: 11, April 5.

Schutte, H.J. 1984. 'n Poëtika van korrespondensies: Angelliera en Jukstaposisie. In : Viljoen, H., Grábe, I., Jooste, E. en Steenberg, D. (reds.): In teen die groot vergeet. Potchefstroom : PU vir CHO. p. 93-107.

Scharfstein, B. 1973. Mystical Experience. Oxford : Basil Blackwell.

Spangenberg, D.F. 1990. T.T. Cloete : poësie as étalage. Van pyn tot pret... Rapport: 17, Maart 4.

Spencer, S. 1966. Mysticism in World Religion. London : George Allen \& Unwin.

Van Zoest, A.J.A. 1978. Peirciaanse semiotiek. In: Grivel, C. (red.) Methoden in de literatuurwetenschap. Muiderberg : Dick Coutinho. p. 102-114.

Van Zyl, I. 1990. T.T. dig slim oor Skepping. Die Republikein: 5, Junie 29.

\section{Universiteit van die Oranje-Vrystaat}


